\title{
Kionaster petersonae, n. gen. and sp. (Asteroidea), the first fossil occurrence of the Asterodiscididae, from the Miocene of Florida
}

\author{
Daniel B. Blake $\cdot$ Roger W. Portell
}

Received: 21 June 2010/ Accepted: 2 September 2010/Published online: 15 December 2010

(C) Akademie der Naturwissenschaften Schweiz (SCNAT) 2010

\begin{abstract}
Kionaster petersonae, n. gen. and sp., from the Miocene Chipola Formation of Florida, is the first-known fossil member of the extant family Asterodiscididae Rowe. Although abactinal and marginal expressions clearly serve to distinguish the Asterodiscididae, the family was recognized only relatively recently, in part perhaps because assigned genera are few and these occur in traditionally less heavily collected areas. The original inferred presence of reduced numbers of marginal ossicles in the family is rejected. Phylogenetic analysis suggests close affinities between asterodiscidids and Goniaster L. Agassiz, 1836 (Goniasteridae). Kionaster appears closest to the eastern Pacific asterodiscidids rather than Asterodiscides itself, which is widely distributed farther west in the Pacific. Distinctive characters of Kionaster suggest a once-greater diversity within the family. Although data are limited, morphologic similarities and biogeographic distributions suggest familial origin in a low-latitude Western Hemisphere setting and the Atlantic Ocean prior to the closing of the Isthmus of Panama.
\end{abstract}

Keywords Asteroidea - Asterodiscididae - Miocene . Chipola formation $\cdot$ Florida

\footnotetext{
D. B. Blake $(\bowtie)$

Department of Geology, University of Illinois,

Urbana 61801, USA

e-mail: dblake@uiuc.edu

R. W. Portell

Florida Museum of Natural History,

University of Florida, Gainesville 32611, USA

e-mail: portell@ flmnh.ufl.edu
}

\section{Introduction}

More or less complete fossil asteroids are almost always rare. Although dissociated ossicles are common at many Cenozoic localities in the state of Florida, USA, very few articulated specimens and specimen fragments have been reported. The present paper began as a descriptive study of a remarkable specimen of a new genus and species of the family Astrodiscididae from the Florida Miocene (Figs. 1, 2). The Astrodiscididae was previously unknown from the fossil record and the new genus is an important addition to asteroid history. Other occurrences of Florida fossil asteroids were summarized by Blake and Portell (2009).

It was quickly realized that aspects of morphology of asterodiscidids had to be re-evaluated before other interpretive work and a formal description could be undertaken. After consideration of the specimen and its stratigraphic setting, morphology of the Asterodiscididae is interpreted, followed by a phylogenetic survey of asterodiscidids and similar valvatidan asteroids. Biogeography and functional morphology are then treated, followed by systematic treatment.

Kionaster petersonae $\mathrm{n}$. gen. and sp. is assigned to the family Asterodiscididae, which until this report was known only from extant species. Comparatively few papers treating asterodiscidids are available. The family was described by Rowe (1977) and other papers treating representatives include Ludwig (1905), Fisher (1906), Rowe (1985), Oguro (1991), Liao and Clark (1995), and Lane and Rowe (2009). Rowe (1977) provided a literature review. Four extant genera have been included, Paulia Gray, 1840, Amphiaster Verrill, 1868, Asterodiscides Clark, 1974, and Pauliella Ludwig, 1905. Rowe (1977) tentatively synonymized Pauliella with Paulia, and he further noted that Ludwig himself suggested that known Pauliella specimens 
Fig. 1 Map of Florida showing collecting locations of Kionaster petersonae, n. gen. and sp.; holotype Florida Museum of Natural History UF 148379 , collected at or very near IP CA018; paratype UF 76112, at IP CA016; paratype UF 74923, at IP CA027. All Calhoun County, Clarksville Quadrangle USGS 7.5', 1990; T1N, R9W
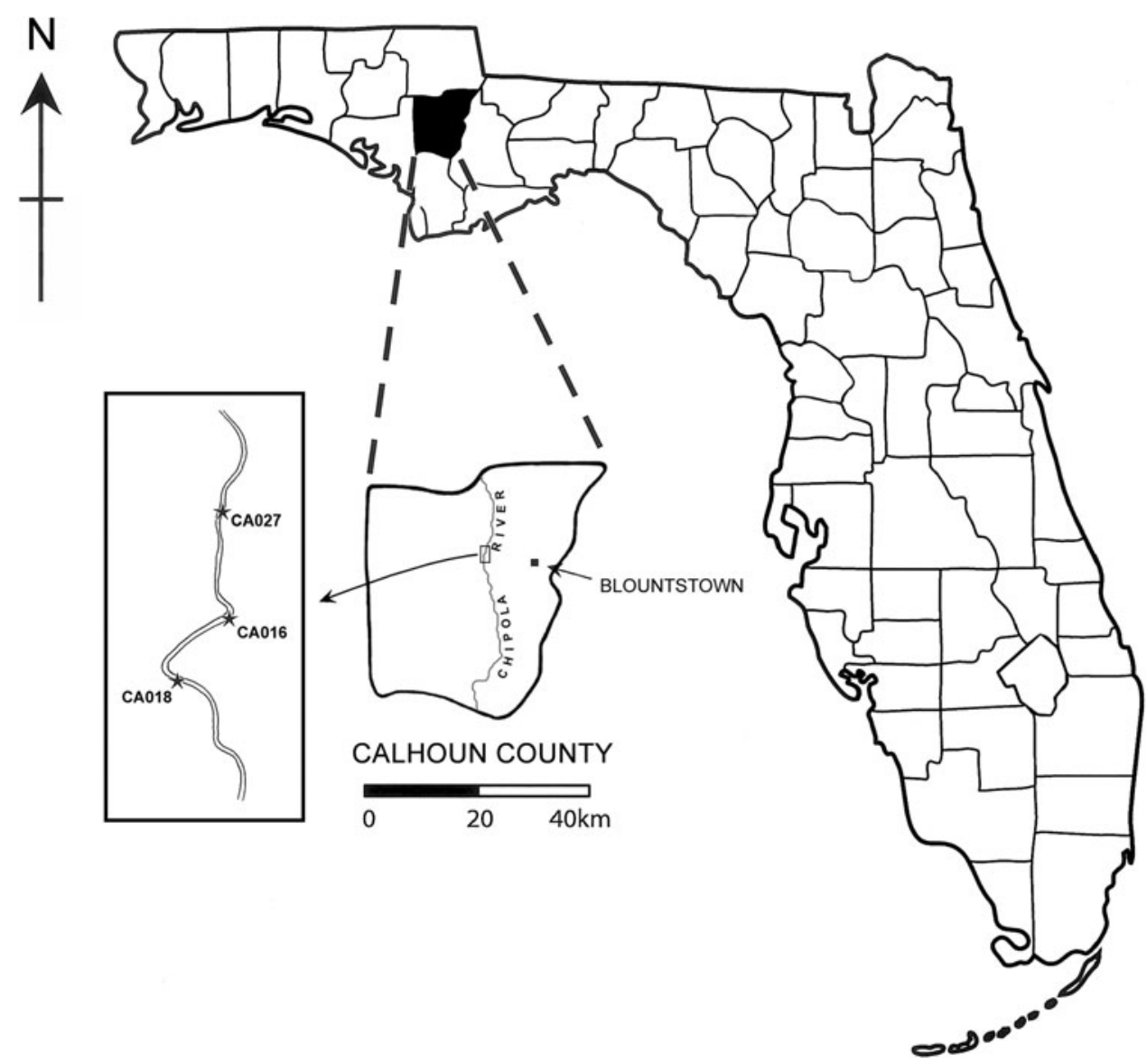

might be only immature Paulia. Pauliella, however, is discussed and included in the cladistic analysis here because of the still tentative nature of the synonymy and also because it exemplifies the goniasterid-like appearance of immature asterodiscidids, a point made by Rowe (1977). Paulia, Pauliella, and Amphiaster are only known from their respective type species and they are restricted to the tropical eastern Pacific (Clark 1993). In contrast, 17 nominal species have been assigned to Asterodiscides. This genus is widespread in the tropical Indo-West Pacific, and it extends to temperate areas of Australia and New Zealand. Whereas the eastern Pacific genera have been collected from the shoreline down to 20-30 m,Asterodiscides is most usually found within a range from 50 to $100 \mathrm{~m}$, although it has been reported from the shoreline to $792 \mathrm{~m}$ (Rowe 1977, p. 215).

Phylogenetic analyses of fossil and recent asteroids, including some similar to asterodiscidids, were undertaken by Mah (2005a, b, 2006, 2007); Villier et al. (2004a, b), and Blake (2010). The character suite developed for Blake (2010) provides the basis for treatment here (Fig. 3), supplemented with characters crafted for the Asterodiscididae.

\section{Terminology}

Terminological usage largely follows Spencer and Wright (1966) and Blake and Hagdorn (2003). Primary ossicles are the more or less enlarged foundation ossicles of the body wall; in contrast, accessory ossicles are the spines, spinelets, granules, and pedicellariae seated on primaries, these minimally developed in Kionaster. In some asterodiscidids, tubercles are enlarged, spine-like prominences that are a part of the primary ossicle itself rather than an independent accessory. A double marginal series (inferomarginals, IM, and superomarginals, SM) arise at the unpaired terminal at the tip of the arm and serve to separate abactinal ossicles of the dorsal surface from the actinal ossicles developed between the marginals and the adambulacrals. Intermarginals are morphologically differentiated primary ossicles positioned between the marginal series. A differentiated primary circlet of abactinals is developed near the dorsal center of the disk, and a differentiated carinal series extends along the dorsal arm midline. The ambulacral and adambulacral series also arise at the terminal and extend proximally to the mouth frame (which is essentially unexposed in the Kionaster holotype). 


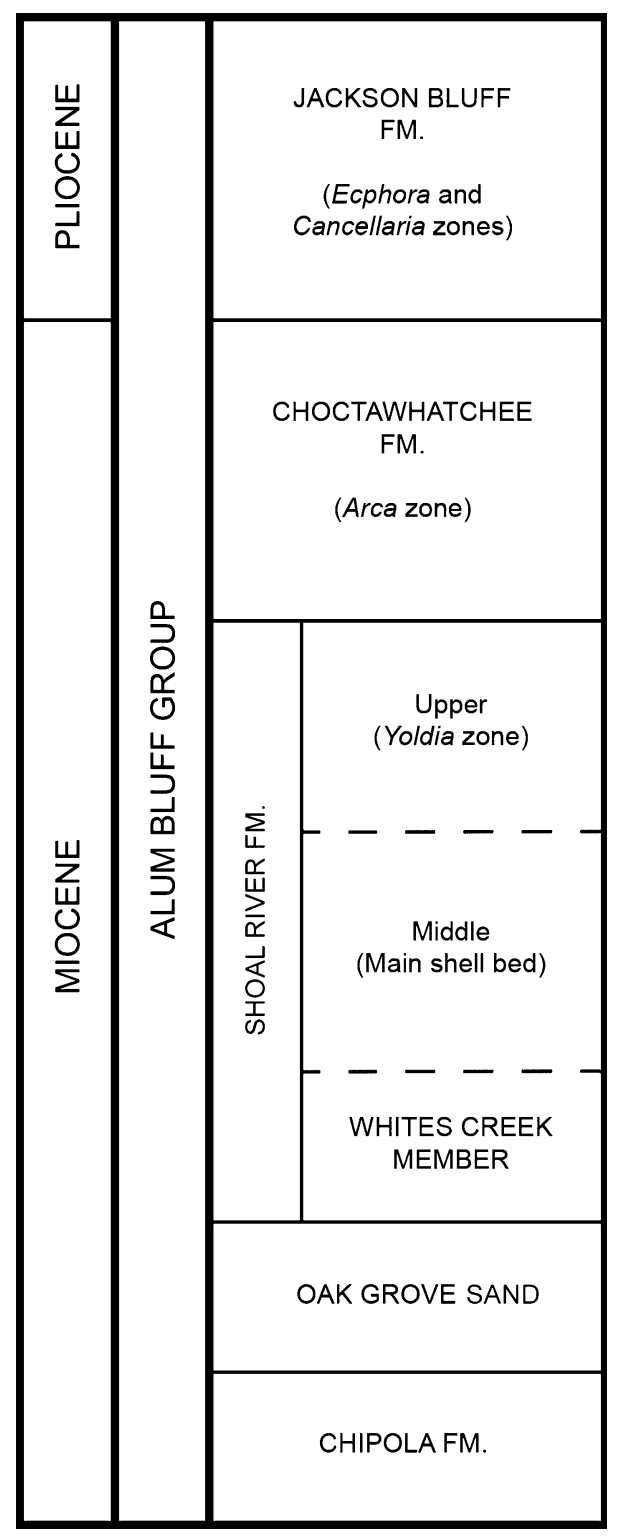

Fig. 2 Stratigraphic arrangement of units in the lower Miocene to Pliocene Alum Bluff Group of Florida (based on Huddlestun 1984)

\section{Stratigraphy}

Kionaster petersonae, n. gen. and sp., is based on new material collected in the Florida Panhandle, southeastern USA (Fig. 1). The source horizon is the Chipola Formation, the lowermost unit of the early Miocene to Pliocene Alum Bluff Group (Fig. 2). Its outcrops, at Alum Bluff on the Apalachicola River in Liberty County and along the Chipola River and its tributaries in Calhoun County, consist typically of a blue-gray to yellow-brown (deeply weathered), unconsolidated, highly fossiliferous marl with quartz sand. At Alum Bluff, the Chipola Formation is unconformably overlain by Jackson Bluff Formation sediments (Huddlestun 1984) and in subsurface is underlain by an erosional remnant of the lower Miocene Torreya Formation (Banks and Hunter 1973). Elsewhere, the Chipola Formation is underlain by the upper Oligocene to lower Miocene Chattahoochee Formation (Vokes 1989; Huddlestun 1984).

Bender (1973), using $\mathrm{He} / \mathrm{U}$ coral dating, estimated an average age of $16.1( \pm 1.0)$ Ma for the Chipola Formation. Akers (1972), using calcareous nannofossils and planktonic foraminifera, suggested correlation of the Chipola Formation to planktonic foraminiferal Zones N7/N8 of Blow (1969), but stated a preferred placement of the unit in Zone N7. Bryant et al. (1992), using $87 \mathrm{Sr} / 86 \mathrm{Sr}$ isotope dating of venerid bivalves, estimated an age of between 18.3 and $18.9( \pm 1.0)$ Ma. Lourens et al. (2004) placed the upper boundary of the early Miocene at $15.97 \mathrm{Ma}$, well within the error range of dates obtained by Bender (1973), and assigned planktonic foraminiferal Zone N7 to the early Miocene Burdigalian Stage (15.97-20.43 Ma). Dates provided by Bryant et al. (1992), although slightly older than those suggested previously, further support a Burdigalian age for the Chipola Formation.

\section{Material}

A single nearly complete, articulated, sand and shell debris encrusted specimen of Kionaster petersonae n. gen. and sp. (Figs. 4c, 5, 6) was collected in June, 2008, at or very near Chipola River locality FLMNH IP CA018, Calhoun County, Florida, in an exposure of the lower Miocene Chipola Formation. Intensive collecting of Chipola Formation outcrops over the past 100 years yielded only many dissociated asteroid ossicles; from this suite, however, two distinctive superomarginals now can be assigned to Kionaster.

The prepared holotype is nearly fully exposed, although the mouth frame and adambulacral series remain largely obscured by highly resistant matrix. The holotype has arm radii of $27 \mathrm{~mm}$ and disk radii of $11 \mathrm{~mm}$. Overall specimen appearance suggests only minor distortion due to sediment compaction, and no significant decay appears to have taken place before final burial because ossicles are little displaced. Because the specimen is nearly intact, data on internal morphology is all but unavailable, although arm tips are variously truncated revealing distal internal ossicles. The arm tips are upturned, a characteristic of many valvatidans in life.

Because preparation techniques can be useful to others, we include the preparator's comments: "The preparation was accomplished mainly using a shortened 'stubby' air scribe designed for use under microscopes with a relatively high objective magnification and short working distance. Additionally, the rest of the mechanical preparation was 


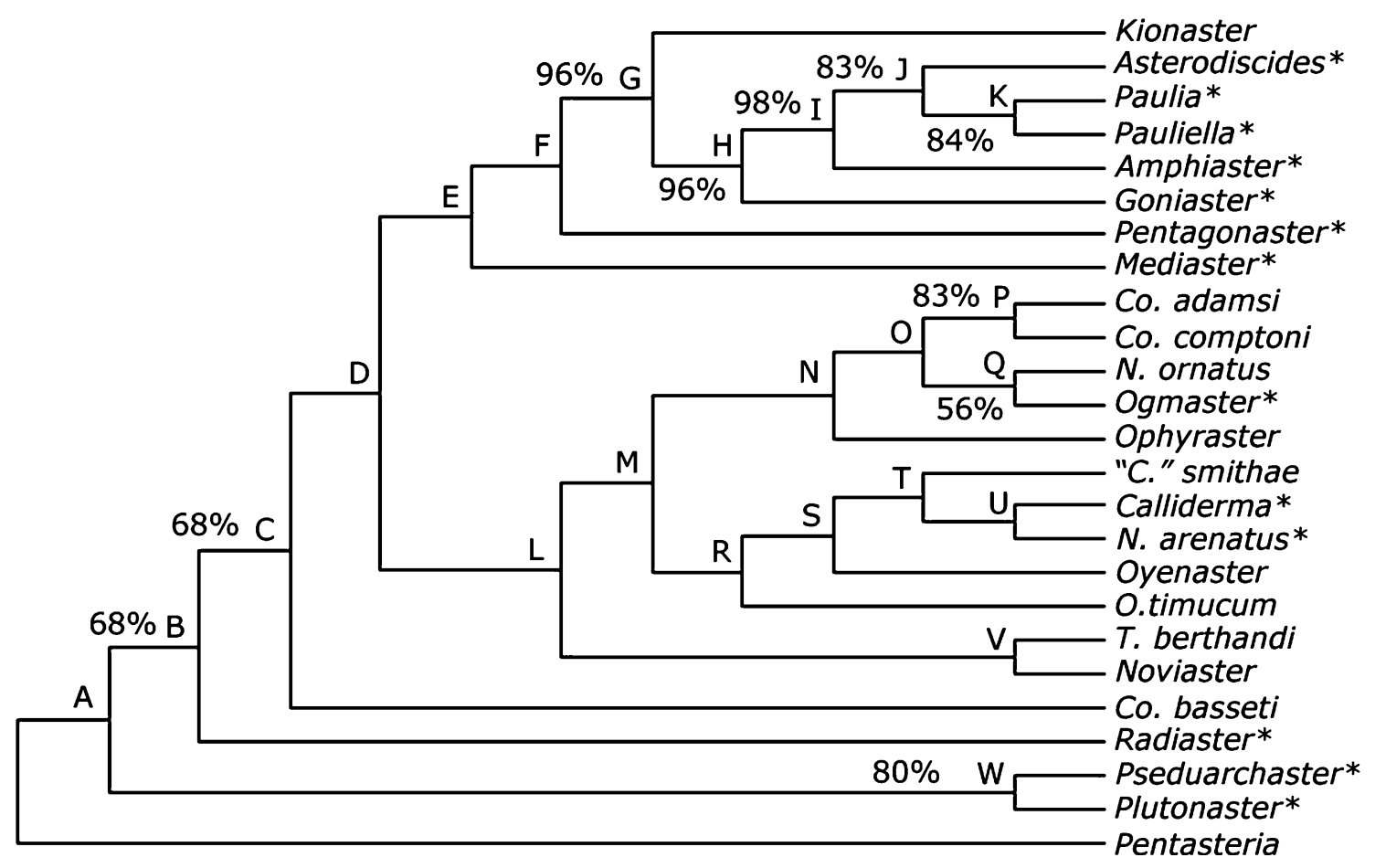

Fig. 3 Phylogeny of known Asterodiscididae and selected similar valvatidan and paxillosidan genera. Bootstrap support values expressed as percentages. * extant genera; Calliderma is the extant C. emma, $C$. is used for specimens previously assigned to Calliderma from the collections of the Natural History Museum, London, see Blake (2010); Co. Comptoniaster; N. Nymphaster; T. Tylasteria; $O$. Ocalaster. For character transformations, nodes are capital letters. Below, state changes for each nodal step are formatted " $m>n$ " and individual characters follow, e.g., for step from node A to node B, characters 4, 20, 64, and 87 go from 0 to 1 and 5, 43, and 52 from 1 to 0. A $>$ B: $0>1,4,20,64,87 ; 1>0,5,43,52$. B $>$ C: $1>0,19,49$, 51; $0>1$, 84. C > D: $0>1,16 ; 1>0,48,81,89$. D > E: $0>1,7$, 49; $1>0,35,90$. E > F: $0>1,17,19,34,38,44,45,80 ; 1>2,33$; $1>0,39,85,91 . \mathrm{F}>\mathrm{G}: 0>1,1,6,14,21 ; 1>0,2,11,15,77$; $2>1,30$. G > Kionaster: $1>2: 1,6,19,20,30,64 ; 1>0,4,8,17$, $21,34,38,47,80 ; 0>1,5,10,22,23,35,39,43,70,71,74,75,82$; $2>1,33 ; 0>2,18,59,60,61,62,63,66,67,68,69,81 . \mathrm{G}>\mathrm{H}$ : $1>0: 8,86 ; 0>1,10,22,25,26,42,43,70,74,76,82,91 ; 2>1$, $32 ; 2>0,33$. H $>$ I: $1>0,4,17,27,80 ; 0>1: 33,51,52,72,79$, 83, 92. I $>$ J: $1>0: 49,82 ; 0>1,73 . \mathrm{J}>$ Asterodiscides: $0>1: 4$, 17, 55, 58, 80. J $>\mathrm{K}: 0>1,3 ; 1>0,22,33$. K $>$ Paulia: no character transformation. $\mathrm{K}>$ Pauliella: $1>0,51,52,72$. I $>$ Amphiaster: $0>1,5,24 . \mathrm{H}>$ Goniaster: $1>0: 19,34 ; 0>1$, 35, 55, 58. F > Pentagonaster: $0>1,1,3,6,12,14,21,63 ; 1>0,2$, $4,11,13,15,49,77 ; 2>1,30 ; 1>2,31 . \mathrm{E}>$ Mediaster: $0>1,17$,

accomplished through the use of very fine tungsten carbide needles in a pin vise. The matrix, silica sand with numerous foraminifera microfossils bound by calcareous cement was very hard and due to its coloration was difficult to distinguish from the ossicles of the sea star. The separation of the matrix from the specimen was hindered by the fact that slight recrystalization of the ossicles had tightly bound the matrix to existing anatomy. In some cases the ossicles which had been partly exposed due to weathering were
$19,26,34,38,42,43,44,45,48,80 ; 1>2,33 ; 1>0,39,85,91$. D > L: $0>1: 7,12,14,49 ; 1>0,13,35,84,90 . \mathrm{L}>\mathrm{M}: 0>1,3$, $17,43,78,79 ; 1>0,8,15 . \mathrm{M}>\mathrm{N}: 1>0,20,47 ; 1>2,33 ; 0>1$, $42,53,58,63,67,80,88 . \mathrm{N}>\mathrm{O}: 0>1,66,68,69 . \mathrm{O}>\mathrm{P}: 0>1,8$, 35, 56; $2>1,33 ; 1>0,42,43$. $\mathrm{P}>$ Co.adamsi: $0>1,1,19,45,48$; $1>0,2,58,88$. P $>$ Co.comptoni: $0>1,29,54,57 ; 1>0,49$. $\mathrm{O}>\mathrm{Q}: 0>1,44,46,65 ; 1>0,53,78,79,80 . \mathrm{Q}>$ N.ornatus: $0>1,10,19,28,37,48,60,62,84 ; 1>2,31 . \mathrm{Q}>$ Ogmaster: $1>0$, $3,39,58,85 ; 0>1,4,9,36,38,50,89 ; 0>2,6 ; 2>1,32$. $\mathrm{N}>$ Ophyraster: $1>0,3,39,49,77 ; 0>1,4,10,34,38,55,89$; $1>2,31,88 . \mathrm{M}>\mathrm{R}: 0>1,36,50,84 . \mathrm{R}>\mathrm{S}: 1>0,17,39$; $0>1,40,46 . \mathrm{S}>\mathrm{T}: 0>1: 10 ; 1>0,43,50,78,79$. T > "C." smithae: $1>0,27,47 ; 0>1,29,44,60,62,65 ; 1>2,33$. T $>\mathrm{U}, 1>0$, 20, 31, 49, $0>2$, 88. U > Calliderma: $1>0,3,64,84,85 ; 0>1,4$, 13, 51. U > N.arenatus: $1>0: 11,33,77 ; 0>1,26,48,63,8089$, 90. $\mathrm{S}>$ Oyenaster: $0>1,1,4,8,48,81 ; 1>0,2,3,77$. $\mathrm{R}>$ O.timuсит: $1>2,16 ; 0>1,19,52 . \mathrm{L}>\mathrm{V}: 1>0,11,64$; $1>2,16$. $\mathrm{V}>$ T.berthandi: $1>2,33 ; 0>1,4,34,38,48 ; 1>0$, 39. $\mathrm{V}>$ Noviaster: $0>1,5,35 . \mathrm{C}>$ Co.basseti: $0>1,1,9,16,78$, 79,$88 ; 1>0,2,8,48,77,81 . \mathrm{B}>$ Radiaster: $0>1,18,59,61,84$; $1>0: 19,35,39,47,49,51,86,89,91 ; 2>1,30,32$. A > W: $0>1$, 4, 20, 60, 62, 64; $1>0,5,43,52 ; 1>2,31,33,48 . \mathrm{W}>$ Pseudarchaster: $0>1,7,17,78,87 ; 1>0,49,77,91 . \mathrm{W}>$ Plutonaster: $1>0,19,39 ; 0>1,38,42,79,80,88$

hollow. This was due to the action, presumably, of plant roots and these voids had to be filled with Polyvinyl Buteral B-76 to prevent their collapse. Forams in particular looked dauntingly like small ossicles and had to be exposed and removed on a case by case basis. Work with the air scribe was facilitated by removing the matrix down to within a fraction of a millimeter of the sea star's surface. At this point if the matrix was wetted the ossicles would show clearly through the transparent sand grains. On larger 


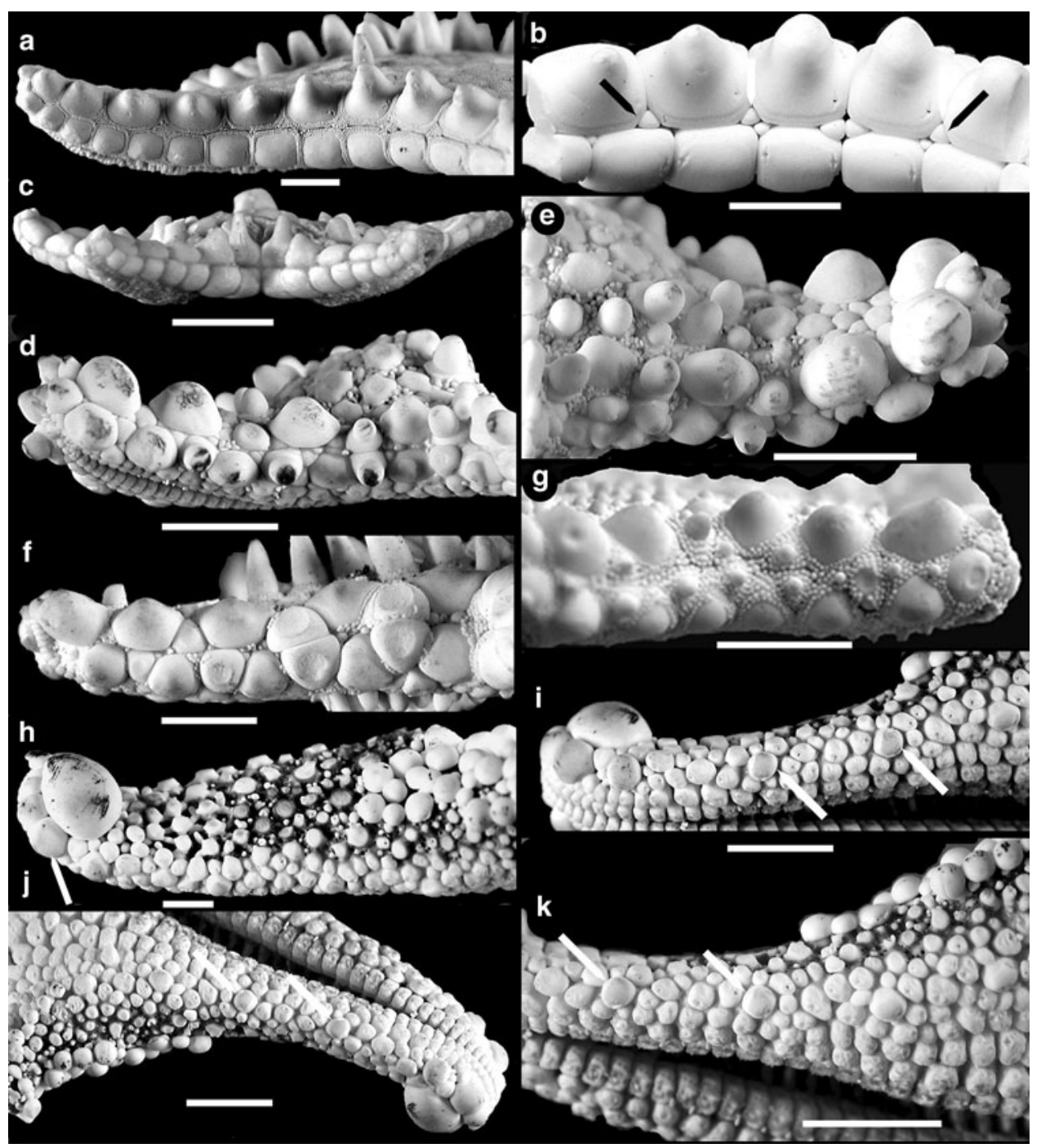

Fig. 4 Arrangement of marginals and related ossicles. Scale bars, a, d-h $5 \mathrm{~mm} ; \mathbf{b}, \mathbf{c}, \mathbf{i}-\mathbf{k} 10 \mathrm{~mm}$. a, b, Goniaster tessellatus (Lamarck 1816), USNM Division Echinoderms E06716, a, uncleared arm and interbrachium, marginals edged by granules, superomarginals bear tubercles, abactinals with spines; b, interbrachial arc, granules cleared, intermarginals (arrows); c, Kionaster petersonae n. gen., holotype, UF 148379, interbrachium, tubercles forming prominences; d, e, Paulia horrida Gray, 1840, USNM Div. Ech. 38087, partially cleared; d, distal lateral view of arm and interbrachium shows both larger and smaller marginals, IM ossicles more numerous, intercalated intermarginals, a few granules remain; e, dorsal-lateral with

ossicles, air scribing would resume after wetting. The transparency would immediately disappear through drying and work would proceed by memory until a slight texture change or nervous discomfort would indicate that re-wetting the specimen was necessary. For smaller ossicles preparation was done entirely while the specimen was wet using carbide needles $1 / 32$ of an inch thick. Total prep time took an estimated 270 h." (Matt Smith personal commun. to RWP, May 2010). enlarged distal SM ossicles; f, Amphiaster insignis Verrill, 1868 , USNM Div. Ech. 39862, partially cleared; lateral view of arm and interbrachium, marginal ossicles are robust and closely spaced, some granules remain; g, Pauliella aenigma Ludwig 1905, USNM Div. Ech. 102006, lateral view of disk and interbrachium, marginal ossicles are robust and closely spaced, granules obscure ossicular boundaries; h-k, Asterodiscides truncatus (Coleman, 1911), USNM Div. Ech. E10144, partially cleared arm, h, arrow identifies row of marginals below enlarged distal SM, i, k, arrows identify two marginals from different perspectives; dark boundary above marginals is the edge of the abactinal papulate field, see text for discussion

\section{Aspects of morphology of the Asterodiscididae}

The Asterodiscididae was recognized only relatively recently for three extant genera and because few specimens were available to its author, Rowe (1977, p. 211) expressed uncertainty as to the status of Pauliella (as noted above) and also as to whether Paulia and Amphiaster should be separated. The original diagnosis of the family was detailed, reflecting both the morphologic complexity of the 
Fig. 5 Kionaster petersonae, $\mathrm{n}$. gen. and sp., holotype, Florida Museum of Natural History UF 148379, Chipola Formation, Florida. Scale bars $5 \mathrm{~mm}$. a, dorsal view of entire specimen; b, dorsal view of disk; doublepointed arrows identify outer disk ring abutting 1 st SMs; single-pointed arrow to right identifies upturned ossicle in outer ring; two single-pointed arrows toward top identify endmembers of five primary circlet (?) ossicles; the base of the left arrow identifies the upended ossicle in the ring of five. Single-point arrow on third of primary circlet (?) identifies centrale (?); c, inclined view of northwest interbrachium of Fig. 5a; arrow here and on Fig. 5d identifies upturned ossicle of Fig. 5b; d, disk and southwest arm of Fig. 5a; e, disk and southeast arm of Fig. 5a; arrows on Fig. 5e-h identify SM and SM/IM marginal pairs; $\mathbf{f}-\mathbf{h}$, side views of north, south east, and north arms of Fig. 5a showing different expressions of the two marginal series and tuberculate proximal SMs; no intermarginal papular pores can be identified although junctions are partially obstructed

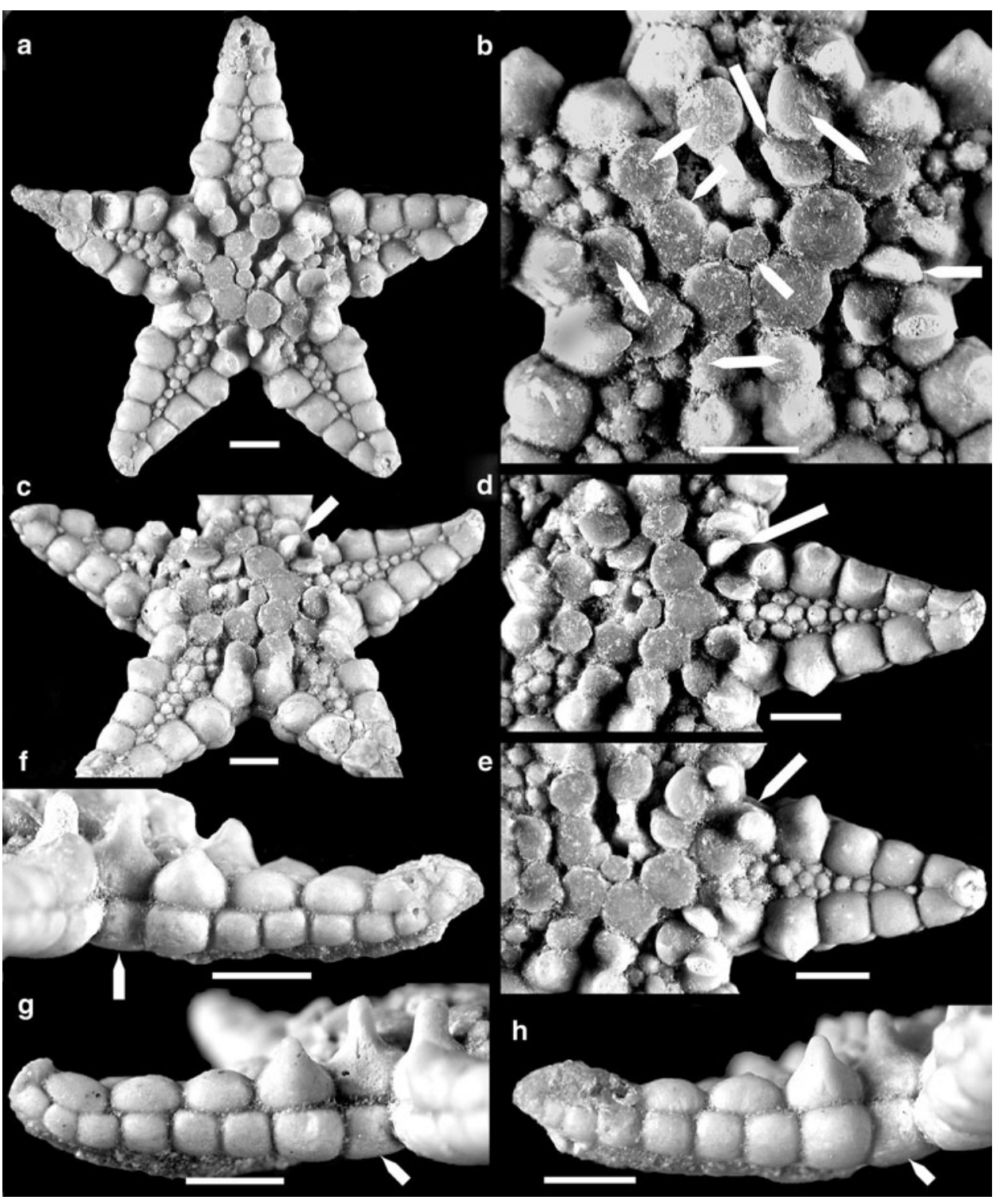

family and its distinctive nature. Rowe (1977, p. 190) recognized presence of only three to five superomarginal ossicles on each side of the arm in all family members, the superomarginals inferred to become separated from each other as the animal increases in size by intercalated abactinal ossicles and intermarginals. Inferomarginals were seen as more numerous than superomarginals, ranging in number from eight to eighteen, these becoming separated by actinals and intermarginals during growth. Liao and Clark (1995), who provided a later summary diagnosis, in essence supported Rowe's marginal number interpretations. In his diagnosis for the then-new species Asterodiscides culcitulus, Rowe identified presence of only four superomarginal ossicles on each side of the arm, and he further illustrated (Rowe 1977, fig. 1) a number of specimens of arm radii under $15 \mathrm{~mm}$ in which the inferred full compliment of abutted superomarginals already are in place. Implicit in these interpretations is that after an early stage of growth, superomarginal genesis is terminated. Correlated with the loss of regularity during growth, papulae of Asterodiscides and individual Amphiaster were thought to extend beyond the abactinal field to the inferomarginals. Rowe further noted that young asterodiscidids are similar to young goniasterids and oreasterids.

Marginal expressions proposed by Rowe $(1977,1985)$ and Lane and Rowe (2009) are not only important to the systematic treatment of asterodiscidids and to historical reconstruction, they are also important to understanding the scope of phylogenetic potential within the Asteroidea; marginal expression therefore is considered here in some detail. For the most part, marginal ossicles of asteroids are 
Fig. 6 Kionaster petersonae, n. gen. and sp., holotype, Florida Museum of Natural History UF 148379, Chipola Formation, Florida. Scale bars a, c $5 \mathrm{~mm}$; $\mathbf{b}, \mathbf{d}-\mathbf{j} 3 \mathrm{~mm}$. a, ventral view of entire specimen, damaged arm tip to southeast is to northwest of $6 a ; \mathbf{b}$, fine surface pustules typical of primary ossicles, north arm of $6 \mathrm{a} ; \mathbf{c}, \mathbf{d}$, ventral of northeast and southeast arms of $6 \mathrm{a}$; d, proximal adambulacrals exposed in lower ambulacra, upper arm with sedimentary debris; e, tip of southwest arm of $6 \mathrm{a}$; distal adambulacrals, a few truncated furrow spines remain; $\mathbf{f}$, tip of southwest arm of $6 \mathrm{a}$, arrangement of distal abactinals, vaulted ambulacral pair at truncated terminus; $\mathbf{g}$, proximal adambulacrals and actinals; first actinal pustule-like structure to right is lighting and surface damage; $\mathbf{h}, \mathbf{i}$, two focal levels of northwest arm of $6 a, h$, upturned tip with adambulacrals, terminal missing; $\mathbf{j}$, north arm of $6 \mathrm{a} ; \mathbf{i}, \mathbf{j}$ lateral profiles of first (upper arrows) and second (lower arrows) SM tubercles, the second SM tubercle to viewer's left broken in both; apparent notching below 2nd SMs is curvature of tubercle, not grooving between marginal series

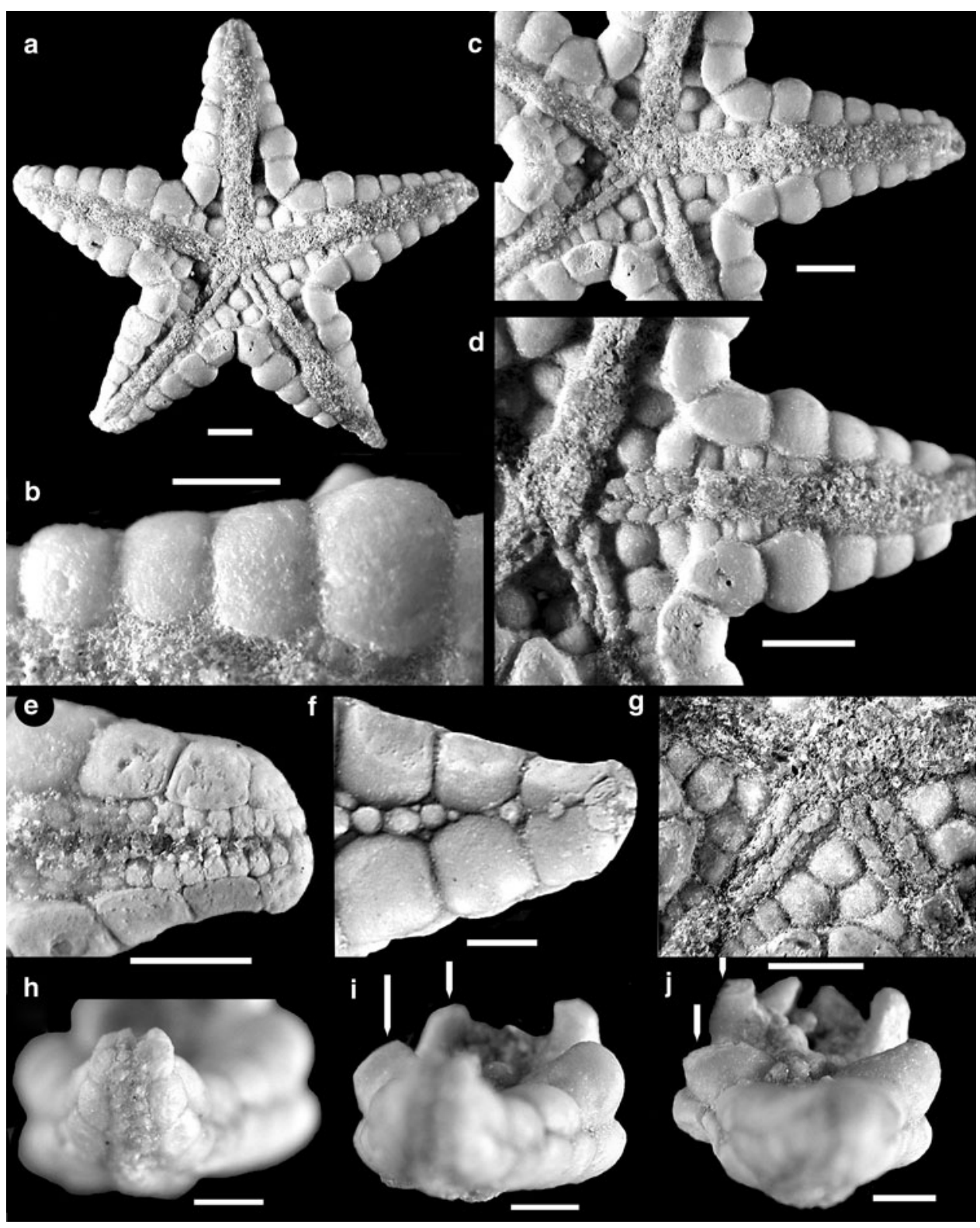

quite uniform whereas those of the Asterodiscididae, as noted by Rowe (1977, 1985), are irregular; however, it is argued here that marginals of asterodiscidids are numerous and form an essentially continuous series, as is more typical among asteroids. Present argumentation is based on the extant genera included by Rowe as well as Kionaster $\mathrm{n}$. gen. and Goniaster, the latter included by Mah (2005a) with the asterodiscidid genera in a separate subfamily of the Goniasteridae (Fig. 4).

The first concern must be basis for the recognition of marginal ossicles. Traditionally, this has not been an issue in the study of extant asteroids because the double series of many or most taxa is relatively readily recognized. Further, status is quite clear where marginals are either apparently absent (e.g., Pterasteridae) or very incompletely developed (e.g., order Brisingida).

Consistent morphological expressions useful for marginal recognition are not easily identified (Blake and Hagdorn 2003; Blake and Elliott 2003). As seems at least implicit in the publications of earlier workers, regardless of other criteria, marginal ossicle series always arise immediately proximal to the terminal (Blake 1978). Even if it were to be argued that site of series origin is a criterion of choice, it remains important because of its objectivity. The terminal superomarginal is much expanded in A. truncatus (Coleman, 1911) as well as in other species of Asterodiscides (Fig. 4h-j). A series of four to six smaller apparent marginals lie beneath most of the expanded marginal, this 
series opening proximally to be joined by smaller abactinals, intermarginals, and actinals. The simplest explanation is that offset in timing of marginal formation expressed in many asteroids (as evidenced by offset of marginals of the two series along the arm, e.g., Fig. 4c) is accentuated at the arm tips of $A$. truncatus. Perhaps most striking is the differential growth of arm-tip marginals in Asterodiscides as well as in certain other asteroids, e.g., Pentagonaster Gray, 1840; at least in Asterodiscides, the enlarged SM is shunted aside. Rowe (1977, 1985) did not specifically identify his series recognition criteria; however, his discussions suggest he relied on ossicular size and perhaps accessory presence: Although accessory ossicles are abundant in Asterodiscides, in some species intermittent larger apparent marginals are distinct because they are bare (e.g., Rowe 1977, fig. 2b, e; Fisher (1906), p. 28.3). Smaller associated ossicles apparently were identified based on positioning, for example, inferred abactinals that seemingly intruded into the marginal series.

In order to understand asterodiscidids, it is useful first to briefly treat why variability of expression might exist. Spencer $(1915,1920)$ and Schuchert (1915) both thought the small-marginal condition ("cryptozonate") arose multiple times from the large-marginal condition ("phanerozonate"). Spencer (1915, p. 63) argued young cryptozoans go through a phanerozonate stage, providing the functional interpretation that a cryptozonate condition offers increase in surface area availability for respiration. He also argued (1920, p. 202) that large marginals are found in taxa with rectangular arms whereas differentiation is obscured in taxa with rounded arms in part because in the cylindrical form, "each ossicle has ample room to grow and rows are not subject to unequal lateral pressures." Perhaps more simply, in cylindrical arms, ossicular rows are more nearly functionally equivalent. O'Neil (1989) argued that ossicular and tissue arrangements in the Echinasteridae allow arm flexibility; echinasterids have cylindrical arms and arm body wall ossicles of approximately uniform size. Marginal configuration between the phanerozonate and cryptozonate conditions tends to be intermediate in intermediate body shapes, such as the thickened Oreasteridae, which commonly have enlarged disks and flat ventral surfaces.

The present writers disagree with the assessment of Rowe that few marginals are present in asterodiscidids. Rather, they argue that ossicles of both series are numerous and essentially continuous albeit irregular.

Individual interpretation of marginal number in asterodiscidids is insufficient because there is no way to compromise differences of weighting of recognition criteria. Perhaps the ideal approach would be documentation of growth series, which is currently unavailable. Lacking that, treatment here begins with a hypothesis of monophyly among the genera (Fig. 3) and argues that the five (or six, depending on the status of Pauliella) can be arranged in a morphologic gradient beginning with flattened Goniaster and continuing with Kionaster n. gen., Paulia, Amphiaster, and finally Asterodiscides (Fig. 4).

The marginal series of Goniaster (Fig. 4a, b) are paired and similar; however, typical asterodiscidid expressions include abundant granules, present in Goniaster only around the edges of the marginals (Fig. 4a), and presence of small ossicles at the junctures of marginals (Fig. 4b, arrows); the latter, distinguished by size, shape, and position, are intermarginals (see discussion below). In Kionaster (Figs. 4c, 5 and 6), marginals are unpaired and bare and the superomarginals are bulbous. There is no suggestion of intermarginals. Distinctive enlarged, plate-like disk abactinals occur in both Goniaster and Kionaster (Fig. 5a-e).

We argue that the essential structure of the argument on marginal presence would survive rejection of Goniaster as an asterodiscidid because specimens of Paulia (Fig. 4d, e; $R=33 \mathrm{~mm}$ ), Pauliella (Fig. $4 \mathrm{~g} ; \quad R=25 \mathrm{~mm}$ ), and Amphiaster (Fig. 4f, $R=35 \mathrm{~mm}$ ), although exhibiting considerable irregularity of appearance, have series of ossicles readily recognized as marginals extended the full length of the arm. This is true even of a larger Amphiaster specimen, which, because of its size, might be expected to have entered the stage of posited marginal separation.

It is marginal arrangement of Asterodiscides that is most readily debated (Fig. $4 \mathrm{~h}-\mathrm{k}$ ). Presence of smaller ossicles, especially away from the tip of the arm, suggests marginal series discontinuity, with perhaps only the larger ossicles (Fig. 4h-k, arrows identify the same ossicles) representing marginals. However, the generic series from Goniaster (or even Kionaster and Paulia) to Asterodiscides goes from flattened to rounded, with both overall form and proportionate ossicular sizes of Asterodiscides reminiscent of corresponding expressions of, e.g., Echinaster (see O'Neil 1989) rather than Goniaster. We argue from parsimony: The simplest explanation is to posit differential growth within the marginal series, consistent with the trend seen elsewhere in asteroids, as suggested by Schuchert (1915) and Spencer (1920), and in most asterodiscidids (Fig. 4c-g). Interruption of marginal sequence is infrequent (e.g., Brisingida, Mithrodidae) and further, even in these taxa, marginals continue to develop through life as can be seen by abutted distal marginals. Similarly, continuity of the apparent marginal series beneath the enlarged distal SM of a fairly large specimen of Asterodiscides (Fig. 4h-k) favors continuity of marginal formation rather than an intermittent process. We are aware of no example of termination of marginal genesis, as is implicit in interpretations and figures of Rowe (1977), if small asterodiscidids already have the full compliment of marginal ossicles. An additional evolutionary complexity arises if it is posited that marginals stopped forming at an early growth stage. According 
to such a termination hypothesis, and because many smaller ossicles are present along the arm (Fig. 4h-k), selective pressures immediately replaced marginal ossicles with smaller but otherwise similar and seemingly functionally equivalent abactinals and actinals. We find proportionate size reduction of marginals to be the more parsimonious hypothesis and also in accord with changes seen in other asteroids, a hypothesis requiring no peculiar phylogenetic event, that of termination of marginal ossicle formation. Proportionate size reduction eases intrusion and irregularity of arrangement of ossicles, and it can reflect changing ossicular function sensu O'Neil (1989). Partial abactinal intercalation is also known in the extant Mithrodidae and the fossil Trichasteropsiidae (Blake and Hagdorn 2003). The interpretation suggested here does not enable ready assignment of individual ossicles to series in Asterodiscides, although more complete growth series should help.

Two other important features, presence of intermarginal ossicles and papulae extending between the superomarginals to the inferomarginals, were recognized by Rowe (1977, 1985). Intermarginals in taxa in which these ossicular series traditionally have been recognized (e.g., Asteriidae, Echinasteridae) are a part of the primary ossicular system in that they form a part of the body wall rather than resting on other ossicles; superimposed ossicles such as granules and pedicellariae are accessory ossicles. Intermarginal expression is distinct in asteriids and echinasterids and a close phylogenetic connection has not been suggested for them; "intermarginals" evolved independently in the two families.

Interpretation of asterodiscidids can be difficult because of irregular morphology; putative intermarginals include both ossicles that appear be a part of the body wall as well as those that rest on larger marginals and hence might be simply enlarged granules. Expression in Goniaster is relatively clear because of the very regular development of marginals (Fig. 4a, b). Putative intermarginals appear distinct in morphology but still clear in Paulia and Amphiaster (Fig. 4d-g). Recognition is more problematic in Asterodiscides (Fig. 4h-k) but consistent with their presence in Paulia and Amphiaster. Intermarginal presence therefore is deemed available for coding in the phylogenetic analysis here. The distinctive asterodiscidid intermarginal expression suggests no close phylogenetic linkage between this family and echinasterids or asteriids.

Rowe $(1977,1985)$ interpreted presence of papulae extending beyond the abactinal field into the marginal series to the inferomarginal line in Asterodiscides and individual specimens of Amphiaster. We have not seen such occurrence in available Amphiaster, and because marginal series of Asterodiscides are difficult to trace, papulae positioning is difficult to determine with finality.
The ventral boundary of the papulate area is quite sharp in our specimen (Fig. 4h-k) because it is identified by presence of dark coloration, which is organic tissue. We argue that distribution of enlarged ossicles in A. truncatus strongly suggests that marginals occur below the darkened zone and therefore that this contact can be interpreted as marking the abactinal-superomarginal boundary. Mah (2005a) did not recognize intermarginal papulae in goniasterids and related families of asteroids, including asterodiscidids. Our positioning of the superomarginal sequence is parsimonious in requiring no new evolutionary event for these valvatidan asteroids. Putative positioning of papulae within the marginal series therefore is rejected here and it is not recognized in our phylogenetic character listing.

\section{Phylogenetic evaluation and significance of Kionaster n. gen}

Background

The present phylogenetic evaluation is a survey study seeking to position Kionaster and other asterodiscidid genera among probable stemward goniasterid-like valvatidans and paxillosidans. No comprehensive phylogenetic analysis is available for the Asterodiscididae, although Lane and Rowe (2009) included a cluster analysis of species of Asterodiscides.

Phylogenetic analysis here is based on that of Blake (2010), which was developed to evaluate relationships of a new Cretaceous goniasterid from Texas of the specious then-hitherto exclusively European Jurassic and Cretaceous genus Comptoniaster. Characters developed for that study began with Comptoniaster and other apparently stemward goniasterids (sensu Mah 2005a). Unfortunately, postPaleozoic fossil asteroids are rare and few even partial specimens are available. Character selection therefore focused on phanerozonate (i.e., enlarged) marginals because these have provided the bulk of the fossil record. This emphasis suffers from serious limitations. Marginal form is quite simple yet changes with ontogeny and position on the parent specimen; further, ossicular surfaces are complexly curved and therefore difficult to characterize objectively in simple phrasing. As a result of these limitations, distinct character categories are difficult to develop and coding can be subjective.

In the present study, as in Blake (2010), the superficially goniasterid-like Jurassic astropectinid Pentasteria Valette, 1929, was selected as the outgroup. In order to provide control, the extant stemward paxillosidan Radiaster Perrier, 1881, was added, as well as the astropectinid Plutonaster, and the astropectinid-like Pseudarchaster, the last 
traditionally considered to be a goniasterid but recognized at the subfamilial or familial level in different treatments. A number of extant goniasterids were also retained from Blake (2010), and these were augmented by three at least superficially asterodiscidid-like goniasterids: Goniaster, Mediaster Stimpson, 1857, and Pentagonaster. In the phylogenetic analysis of Mah (2005a), Goniaster emerged with the three asterodiscidid genera sensu Rowe (1977), and the four were assigned to a separate subfamily of the Goniasteridae. The three additions here share body proportions (fairly short, broad arms and large disks) and aspects of ossicular form with asterodiscidids, although ossicular form to some extent is correlated with overall body form (e.g., Blake 2010). (Correlation of marginal-based taxonomy with body form is in need of study; this work might be undertaken using extant species that change significantly in body proportion during ontogeny.)

Phylogenetic analysis here is preliminary, in part because of uncertainty regarding many asterodiscidid species and because of incomplete available data. In addition, individuals of many taxa appear quite variable and coding of certain characters is subjective. Asterodiscides includes 17 nominal species (Lane and Rowe 2009); coding here is restricted to $A$. truncatus because of available material. Attempts to span more broadly from the literature introduced much subjectivity of interpretation and the effort was abandoned.

\section{Results}

Phylogenetic analysis used PAUP version $4.0 \mathrm{~b} 10$ for Macintosh. Twenty-five fossil and extant species and genera were coded for 92 primarily binary characters. Of the 92 (Appendix 1), 12 proved uninformative although they are retained (Table 1 in Appendix 2) because they are deemed potentially useful for future work. All characters were unordered and assigned equal weight. Analysis with 100 heuristic search repetitions yielded two equally parsimonious trees. Characters were reweighted once according to rescaled consistency index (RC), and heuristic search yielded one tree (Fig. 3) of consistency index (CI) = 0.6014 , retention index $(\mathrm{RI})=0.7406$, and rescaled consistency index $(\mathrm{RC})=0.4454$.

The first branches (Fig. 3) above the outgroup include the extant paxillosidan Plutonaster and the paxillosidanlike Pseudarchaster followed by the basal paxillosidan Radiaster and the early (Jurassic) goniasterid Comptoniaster basseti; these groupings are consistent with traditional systematic interpretation. A dichotomy above $C$. basseti separates asterodiscidids and a grouping of asterodiscididlike goniasterids from a complex of goniasterid genera. Although character selection did not refine relationships among the latter group, the Jurassic goniasterids Noviaster and Tylasteria berthandi are basal and the Cretaceous species of Comptoniaster ( $C$. adamsi and C. comptonia) paired; the similar Calliderma and fossils traditionally assigned to Calliderma (see Blake and Portell 2009, for reassessment) are closely placed. Paulia and Pauliella paired, reflecting their similarity as suggested by earlier workers, and Asterodiscides is derived within the family as suggested by Rowe (1977).

Bootstrap analysis (Fig. 3) used default settings from PAUP with 1000 replicates. The asterodiscidid cluster sensu Mah (2005a) is emphasized through loss of linkage to Mediaster and Pentagonaster. The stemward branching sequence is retained, but not surprisingly, linkages among the disparate group of goniasterids are lost. Next, tree length was increased three times by one step at a time to calculate Breimer Support. The astrodiscidid cluster, including Goniaster, was retained for two steps, and the two Cretaceous Comptoniaster species remained together for one step, but other linkages were lost. For the third step, search was terminated after one hundred thousand trees were identified.

Results are considered to support Mah's (2005a) grouping of Goniaster with the asterodiscidids as well as the assignment of Kionaster to the Asterodiscididae. As a sister to the extant genera, Kionaster would appear to represent a distinctive branch suggesting an undocumented familial complexity.

\section{Paleoecology and Biogeographic occurrence}

The Chipola Formation, source of the known Kionaster n. gen. material, was deposited in a nearshore, shallow water, tropical marine environment. The formation is well known for its exceptionally preserved, highly diverse invertebrate fauna. Vokes (1989) estimated over 1100 species of mollusks might be present in the unit. Additionally, Scolaro (1968) recorded 52 bryozoan species and Weisbord (1971) reported 13 coral species. Biofacies represented over the areal extent of the Chipola Formation include "shoreline beach, to lagoonal with oyster reefs, to coral patch-reefs in an offshore back-reef setting probably nowhere deeper than 30 m" (Jones 1997, p. 105). The geographic area in which the holotype of new taxon was discovered (FLMNH IP CA018 = Tulane University locality TU 547), as stated in Vokes (1989), represents a coral patch-reef environment. It is worth noting that north (within $150 \mathrm{~m}$ ) of this locality the holotype of another rare Chipola Formation echinoderm, Rhyncholampas chipolanus Oyen and Portell, 1996, was discovered.

The skeletally robust dorsal surface arguably represents a defensive configuration (Blake 1983, 1990). Inset of the 
proximal-most marginals at the bases of the arms (Figs. 5a, 6a) might have enhanced twisting capacity about the long axis of the arms, thereby abetting flexibility presumably lost with an evolutionary trend toward increased armor.

Rowe (1985, p. 554, 557) and Lane and Rowe (2009) provided extended discussion of history and biogeography of the Asterodiscididae and Asterodiscides in particular. Their interpretations were based largely on consideration of the apparent difficulties encountered by many marine groups in crossing the Pacific Ocean from west to east; Rowe (1985) concluded that the Asterodiscididae probably arose in the mid- or west-Pacific early in the Cenozoic and was then distributed to the west, ultimately reaching the eastern Pacific by way of the Panamanian Isthmus. As this author found Paulia and Amphiaster basal to Asterodiscides, he concluded these eastern Pacific taxa represent relict distributions. The positions of Kionaster and Goniaster Agassiz, 1836, in the phylogenetic analysis here support Rowe's inferred presence of the Asterodiscididae in the Atlantic, but given a derived position for Asterodiscides and the known distributions of extant asterodiscidid genera, Kionaster, and Goniaster, a Western Hemisphere or at least Atlantic origin for the family provides a tenable alternate hypothesis. In a study of the Pacific species-rich hermit crab genus Calcinus, Malay and Paulay (2010) found that diversification in this genus did not track biogeographic patterns recognized for other groups; perhaps the history of the Asterodiscididae, like that of Calcinus, was not as that documented for other groups.

\section{Systematic paleontology}

Order Valvatida

Family Asterodiscididae Rowe 1977

\section{Discussion}

Rowe (1977) discussed earlier familial assignments of asterodiscidid genera; his grouping was supported by Mah (2005a) and these authors are followed here. Kionaster $\mathrm{n}$. gen. is assigned to the Asterodiscididae based on irregular expression of abactinals, relative numbers of the two marginal series, and presence of enlarged tubercles. The bare ossicles of Kionaster suggest a thickened integument, as in other asterodiscidids; accessories are unknown from beyond the furrow series. As described above, presence of many marginals in each series and restriction of papulae to the abactinal surface in Kionaster is here interpreted as consistent with expression in other asterodiscidids.
Genus Kionaster new genus

Type species $K$. petersonae new species; the genus is monospecific

Diagnosis As for the type species

Description As for the type species

Etymology kion, Gr., column or pillar, for the pillar-like tubercles on the proximal superomarginal ossicles; and aster, Gr., star

Occurrence As for the type species

$K$. petersonae new species

Diagnosis

Asterodiscidid with finely pustulate primary ossicles (Fig. 6b). Abactinal ossicles differentiated into two groups, larger disk ossicles and smaller arm ossicles (Fig. 5a). Dorsal disk ossicles enlarged, thickened, and plate-like (Fig. 5a-e). Interbrachial marginals recessed, forming a notch or re-entrant in body outline (Figs. 5a, 6a). First superomarginals on each side of arm bearing a column-like or pillar-like tubercle; second SM bearing a massive, radially flattened tubercle; third and subsequent SMs bulbous but lacking tubercles (Figs. 4c, 5). Actinals arranged in single series, the interbrachial actinal unpaired; actinal ossicular size decreasing abruptly after the third ossicle (counting the unpaired interbrachial ossicle) (Fig. 6c, d).

Description overall form

Stellate, five-armed asteroid, body probably quite low in life. Disk large, arms triangular in plan view, straightsided, tapering evenly toward tips. Interbrachial marginals inset relative to second marginals yielding a notched or re-entrant outline (Figs. 5a, 6a).

\section{Accessories}

A few smaller ossicles (probably reduced primaries) are intercalated among the abactinals (Figs. 5a-e, 6f) but no unequivocal spines, spinelets, granules, or pedicellariae recognized beyond adambulacral spines (Fig. 6e). Ossicular surfaces of better-preserved primaries finely pustulose (Fig. 6b); surfaces likely to have been bare or anchoring dermal thickening; small accessories not suggested by distinct contact scars.

Disk abactinals

Disk abactinals enlarged, plate-like, distinct from smaller, granular arm abactinals. Disk abactinals consisting (Fig. 5b, arrows) of an outer ring of flat, enlarged ossicles, one 
proximal to each of the paired SM at four interbrachia but with an apparent extra ossicle in the fifth; ossicles of this interbrachium are smaller (and disrupted in the single specimen) than those of the remainder. The primary circlet (?) of five ossicles lies within the outer circle, the ring in the specimen with a large gap partially filled by a smaller, nowdisplaced and upended ossicle; smaller ossicle positioned as to parallel edges of separated larger ossicles suggesting this ossicle was fitted in the ring, but also it might have been derived from the ossicular group within the primary circlet (?). Dorsal surfaces of a few disk abactinals might have had small, low, offset prominences but surfaces mostly low, weakly arched. Ossicles within the primary circlet (?) includes an enlarged centrale and three smaller, abutted ossicles similar in size to the upended ossicle.

Arm abactinals

Arm abactinals granular, subspherical, clearly distinct from plate-like disk ossicles (Fig. 5a-e). Arm abactinals in three rows, the medial carinals bordered by one lateral series on each side. More proximal arm abactinals somewhat elongate, more distal abactinals more nearly circular in outline. Larger, more proximal, abactinals somewhat domed, at least some surfaces very finely pustulate. Arm abactinals largely closely abutted, even overlapping; visible possible gaps for papulae few. Carinal abactinal series extending to proximal side of fourth SM, the contact between fourth and fifth with an isolated larger and one or two smaller granules. Lateral abactinal series extend to about the proximal side of the fourth SM, although a small granule or two can occur between the fourth and fifth SM (Fig. 6f).

Contact areas between abactinals of the two abactinal groups suggest disk ossicles might have slightly overlapped the proximal edges of the arm ossicles at edges of outer circlet (Fig. 5b). Although compaction might have abetted overlap, the outer ring ossicles are fitted as to suggest little displacement. The few partially twisted abactinals show no indications of basal connecting rods as found in other asterodiscidids.

\section{Madreporite}

Madreporite not recognized; presumably among the disk abactinals but neither size nor surface texture are distinctive.

\section{Marginals}

Marginal series not paired (Fig. 4c, e-g), superomarginals consisting of five large and one or perhaps two smaller ossicles whereas about nine inferomarginals are preserved (ventral arm tips are less well preserved). Abradial edges of two marginal series not marked by presence of a longitudinal grooving or furrow (Fig. 6e-g). Outer surfaces of successive marginals of both series curving tightly toward intermarginal plane; grooving deep but not marked by distinct ridges or other suggestions of fascioles or accessory differentiation. No indication of intermarginal papulae recognized, although ossicular contacts are not fully exposed (Fig. 5f-h). Marginals of both series appearing finely pustulose (Fig. 6b).

\section{Superomarginals}

Interbrachial SMs inset from second IMs; best-exposed edges suggest first SM slightly enlarged, extended into disk. Superomarginal surfaces expanded, first SMs bearing robust tubercles; these tubercles columnar or pillar-like with remainder of outer face comparatively low. Second SM bearing elliptical, semi-conical tubercle, the long axis radially aligned. Lateral profile of second SM protruding laterally beyond otherwise straight profile of remainder of SM series, and thereby extended to form notched vertical outline of asteroid. Remaining SMs square to weakly rectangular in dorsal outline, surfaces somewhat expanded, bulbous, but not forming tubercles. No indication of enlargement of distal SMs. Adradial edge of SM gradually curved in dorsal view.

\section{Inferomarginals}

Interbrachial IMs distinctly narrower than second IM, which protrudes laterally to correspond to second SM. IMs rectangular in vertical outline, the proximal IMs with long axis radial, ossicles becoming longitudinally elongate distally. Surface bulbous but more weakly so than those of SMs, ventral surfaces nearly flat. Adradial edge of IM distinctly curved in ventral view.

\section{Actinals}

Actinals consisting of an unpaired, enlarged ossicle immediately distal to the MAO and a single series extending along the sides of the arms (Fig. 6a, c, d). Ossicular sizes diminishing abruptly after the third ossicle (counting the unpaired interbrachial), the series reaching to the fourth IM. Actinal outlines polygonal, closely abutting each other and adambulacral and marginal series. The more distal actinals more irregular in size, outline. Actinal outer surfaces weakly arched, surfaces finely pustulose.

Adambulacrals

(Ossicles largely obscured by sand, any remaining spines not clearly separated from adambulacrals in proximal 
ossicles.) Adambulacrals small, proximal adambulacrals elongate parallel to arm (Fig. 6c), those more distal in series weakly transversely elongate (Fig. 6e). Adradially edges appearing flat, distal adambulacrals with about three furrow spines (Fig. 6e), ossicular edge notched to suggest presence of differentiated subambulacrals.

\section{Ambulacrals}

Only tiny distal ambulacrals poorly exposed at truncated arm tips (Fig. 6f), these steeply vaulted and appearing similar to those of many valvatidans. At the arm tips, ossicular material beneath the ambulacrals (i.e., adambulacrals and adambulacral spines) is thick (Fig. 6e, f), indicating a heavily armored arm tip.

\section{Mouth frame}

The mouth frame is not exposed. No internal surfaces other than those exposed at the broken arm tips are visible.

\section{Etymology}

Named for Mrs. Carol Peterson (Cocoa Beach, Florida), who discovered the holotype while fossil prospecting along the banks of the Chipola River.

\section{Material and occurrence}

Holotype UF 148379, consists of a well-preserved, nearly complete, articulated specimen, discovered at or near Chipola 09 (FLMNH IP CA018 = Tulane University locality 547). Calhoun County, Florida, Clarksville Quadrangle USGS 7.5', 1990; T1N, R9W, sec. 29. Chipola Formation (lower Miocene).

Paratype UF 74923, isolated second superomarginal. Chipola 13 (FLMNH IP CA027 = Tulane University 458). Calhoun County, Florida, Clarksville Quadrangle USGS 7.5', 1990; T1N, R9W, sec.20. Chipola Formation (lower Miocene).

Paratype UF 76112, isolated second superomarginal. Chipola 08 (FLMNH IP CA016 = TU 459). Calhoun County, Florida, Clarksville Quadrangle USGS 7.5', 1990; T1N, R9W, sec.29. Chipola Formation (lower Miocene).

\section{Comparisons}

Overall form, reduction of accessories, the distinctive marginal expression, and form of the disk abactinals limit comparisons to asterodiscidids. The re-entrant at the interbrachial angles, the differentiation of the abactinals with enlarged disk and small arm abactinals, the form of the superomarginals and especially their tubercles, all serve to separate $K$. petersonae from previously described asterodiscidids.

In his diagnosis, Rowe (1977) noted presence of internal radiating ossicles linking the primary abactinals; these have not been recognized in Kionaster, although the internal aspects of the primary abactinals are very poorly exposed in the holotype. Rowe (1977) also noted that the skeletal meshes contain groups of papulae although these papulae are not evident superficially; because the single specimen of Kionaster is intact, presence cannot be absolutely eliminated for the new genus but there is no evidence of enlarged fields. Intermarginal ossicles are absent from Kionaster, as are accessories (except for adambulacral spines). Any or all of these features could be plesiomorphic or stemward expressions retained in a phylogenetically early branch, rather than apomorphic, in a Kionaster lineage; the distinctive nature of the genus at least suggests an extinct unknown diversity. Rowe (1977) inferred an unknown ancient asterodiscidid diversity based on biogeography of extant representatives.

Acknowledgments The authors are indebted to C. and B. Peterson for donating the $K$. petersonae holotype to the Florida Museum of Natural History; to M. Smith for his skillful specimen preparation; to J. and L. Toomey for funding M. Smith's position during 2009; to National Science Foundation grant (BRC 0645865) to D. Jones and RWP for curation of the E. and H. Vokes Invertebrate Paleontology Collection (Tulane University); to S. Roberts for drafting Figs. 1 and 2; to C. Mah, who provided photographs of Pauliella, made available USNM specimens of other taxa, to F.H.C. Hotchkiss for useful suggestions; to L. Villier, who kindly provided data on Comptoniaster basseti for cladistic analysis; and to J. Lawrence and A. Smith for reviews. This is University of Florida Contribution to Paleobiology 634.

\section{Appendix 1: Character list}

Body shape

(1) 0 , arm configuration not as 1 or $2 ; 1$, arms short, broad at base, tapering abruptly, margins concave; 2 , arms short, broad at base, tapering abruptly, margins straight

(2) 0 , interbrachial shape not as $1 ; 1$, arms elongate, rather tightly curved at base, tapering gradually

(3) 0 , interbrachial shape not as 1 ; interbrachial arcs broad and somewhat flattened

(4) 0 , interbrachial shape not as 1; 1 interbrachial arcs gradually curved 
(5) 0 , interbrachial shape not as $1 ; 1$, arms straight-sided, interbrachial arc more or less angular

(6) 0 , surface primary ossicles bearing more or less uniform accessory cover; 1, localized bare areas present on some primaries; 2, accessories localized and unknown beyond adambulacrals, MAO

Abactinal surface

(7) 0 , madreporite near disk edge; 1 , madreporite near center

(8) 0 not as 1; 1 multiple abactinal series reach or nearly reach terminal

(9) 0 not as 1 ; 1 , single abactinal series reaches or nearly reaches terminal

(10) 0 , not as $1 ; 1$, marginals abut at arm midlines proximal to terminal

(11) 0 , abactinals not uniform; 1 , abactinals uniform in appearance

(12) 0 abactinal outline not polygonal; 1, outline polygonal

(13) 0 abactinal outline not circular or subcircular; 1 , outline circular or subcircular

(14) 0 , abactinals not tabulate; 1 , abactinals tabulate

(15) 0 , abactinals not paxilliform; 1, abactinals paxilliform

(16) 0 , carinals not differentiated; 1 , carinals present, size differential gradual relative to adjacent series; 2 , carinals distinctly enlarged relative to adjacent series

(17) 0 , pedicellarial alveolae not present; 1 , pedicellarial alveolae present

(18) 0 , abactinal accessories granular; 1 , abactinal accessories spinelets; 2 , none

(19) 0, abactinal edges with border of distinct accessories; 1, abactinal edges lack distinct border of accessories; 2 , none

(20) 0, abactinal small accessories not closely fitted; 1 , abactinal small accessories closely fitted; 2 , none

(21) 0, enlarged papular fields not present; 1, papular fields present

Note: Papular fields can be partally closed by smaller ossicles differing in form from local larger framework abactinals.

(22) 0 , no abactinals, especially those near disk center, distinctly enlarged, subcircular to subpolygonal in outline; 1 , such differentiation present

(23) 0 , ossicular size decreasing more or less uniformly toward interbrachial marginals, distally and laterally on arms (carinals, primary circlet ossicles, papular field ossicles not included); 1, ossicular sizes and/or form locally changing abruptly

Note: This character recognizes arm and disk differentiation of Kionaster; taxa with differentiated carinals, primary circlet are encompassed by " 0 ."

(24) 0, primary abactinal dorsal surfaces not domed nor bearing tubercle; 1 , at least some primary abactinals domed, bearing a tubercle, or both occur in a single taxon

(25) 0, no robust spines known; 1, some abactinals bearing robust spines

(26) 0 , no small rods linking primary abactinals; 1 , such rods present

Marginal ossicles

(27) 0 , not as $1 ; 1$, marginal size increases gradually and uniformly from arm tip to interbrachial plane

(28) 0 , not as $1 ; 1$, marginal maximum breadth near base of arms, breadth decreasing gradually distally, increasing gradually toward interbrachial plane

(29) 0 , not as 1 ; 1 , disk marginals distinctly broader than arm marginals

(30) 0 , interbrachial IM longer than wide; 1 , approximately equidimensional; 2 , wider than long

(31) 0, distal IM longer than wide; 1, approximately equidimensional; 2 , wider than long

(32) 0, interbrachial SM longer than wide; 1, approximately equidimensional; 2 , wider than long

(33) 0, distal SM longer than wide; 1, approximately equidimensional; 2 , wider than long

(34) 0 , interbrachial IM transverse profile not as $1 ; 1$, approximately a section of a circle (convexe sensu Breton, 1992)

(35) 0 , interbrachial IM transverse profile not as $1 ; 1$, curved, more steeply so near abradial margin

(36) 0 , interbrachial IM transverse profile not as $1 ; 1$, angular (approx. busqué sensu Breton, 1992)

(37) 0 , interbrachial IM transverse profile not as $1 ; 1$, humped (approx. bombé sensu Breton, 1992)

(38) 0, interbrachial SM transverse profile not as $1 ; 1$, approximately a section of a circle (approx. convexe sensu Breton, 1992)

(39) 0, interbrachial SM transverse profile not as 1; 1, curved, more steeply so near abradial margin

(40) 0, interbrachial SM transverse profile not as 1; 1, angular (approx. busqué sensu Breton, 1992)

(41) 0, interbrachial SM transverse profile not as 1; 1, humped (approx. bombé sensu Breton, 1992) 
(42) 0 , interbrachial IM longitudinal profile weakly concave to weakly convex; 1 , profile clearly positively rounded

(43) 0 , interbrachial SM longitudinal profile weakly concave to weakly convex; 1 , profile clearly positively rounded

(44) 0 , contact line between interbrachial IMs and actinals straight to weakly convex; 1 , contact line distinctly convex

(45) 0 , contact line between interbrachial SM and abactinals straight to weakly convex; 1 , contact line distinctly convex

(46) 0 , contact zone between SM and IM series not concave or furrowed; 1 , contact zone concave or furrowed

(47) 0, marginal edges abutted longitudinally, forming ossicle-ossicle contact; 1 , marginal peripheral accessories forming the contact

(48) 0 , contact between successive marginals not grooved or furrowed; 1, marginals separated by abrupt, sharply defined grooves, but not true fascioles; 2, true fascioles present

(49) 0, lateral marginal faces lack deeply recessed tissue pads; 1 , deeply recessed tissue pads present

(50) 0 , adradial face articular flanges lacking; 1 , flanges present

(51) 0, enlarged IM spines absent; 1, spines present

(52) 0, enlarged SM spines absent; 1, spines present

(53) 0 , IMs lacking elongate pedicellarial alveolae near to and nearly parallel with abradial margin; 1, alveolae present

(54) 0, IMs lacking elongate pedicellarial alveolae away from abradial margin; 1, alveolae present

(55) 0, IMs lacking short pedicellarial alveolae; 1, alveolae present

(56) 0, SMs lacking elongate pedicellarial alveolae near to and nearly parallel with abradial margin; 1, alveolae present

(57) 0, SMs lacking elongate pedicellarial alveolae away from abradial margin; 1, alveolae present

(58) 0, SMs lacking short pedicellarial alveolae; 1 , such alveolae present

(59) 0, smaller IM accessories mostly or entirely granulate; 1, smaller IM accessories mostly or entirely spinelets

(60) 0 , IM smaller accessories not differentiated in size or form; 1, IM accessories differentiated in size and/or form; 2, accessories not recognized

(61) 0, smaller SM accessories mostly or entirely granulate; 1, smaller SM accessories mostly or entirely spinelets; 2, accessories not recognized
(62) 0, SM smaller accessories not differentiated in size or form; 1, SM accessories differentiated in size and/ or form; 2, accessories not recognized

(63) 0, marginal accessories abutted, or nearly so; 1 , accessories not abutted such that primary ossicle surface clearly visible between accessories; 2, accessories not recognized

Note: This character refers to granule spacing and not areas devoid of granules that occur on marginals of many goniasterids.

(64) 0 , accessory contacts with primaries smooth or pustulate; 1 , accessory contacts with primaries in form of depressions; 2 , accessories not recognized

(65) 0, enlarged, crater-like depressions absent; 1, such depressions are present

(66) 0 , development of IM accessories near SM/IM boundary similar to those of remainder of surface; 1 , these accessories weakly developed; 2, accessories not recognized

(67) 0 , development of IM accessories near actinal (adradial) boundary similar to those of remainder of surface; 1 , these accessories weakly developed; 2 , accessories not recognized

(68) 0, development of SM accessories near abactinal (adradial) boundary similar to those of remainder of surface; 1 , these accessories weakly developed; 2, accessories not recognized

(69) 0, development of SM accessories near SM/IM boundary similar to those of remainder of surface; 1 , these accessories weakly developed; 2, accessories not recognized

(70) 0, IMs not more numerous than SMs; 1, IMs more numerous than SMs

(71) 0 , interbrachial marginals of both series not enlarged or inset from disk edge as to produce a re-entrant in body outline; 1 , these ossicles so differentiated

(72) 0 , individual marginals within the full series grading uniformly in size and/or form; 1, individual marginals within the full series significantly differ in sizes and/or form from adjacent to yield more or less irregular appearance to marginal series

Note: The specialized enlarged terminal or near-terminal marginals are treated below.

(73) 0, distal SMs not enlarged relative to more proximal SMs; 1, some distal SMs so enlarged

(74) 0, no SM outer surfaces extended or bulbous, forming a peaked, attenuated profile; 1, some SM surfaces so extended, but not forming a rodlike process 
(75) 0, no SM outer surfaces with a distinct, tapering, rodlike process; 1 , some SMs with such a process

(76) 0 , intermarginal ossicles not present; 1 , intermarginal ossicles present

Actinal ossicles

(77) 0 , actinals and abactinals dissimilar in size and/or form; 1, actinals and abactinals similar in size and/or form, or at most becoming reduced gradually

(78) 0 , first actinal series not distinctly enlarged relative to second series, or only a single series is developed; 1, first series so enlarged; 2, first actinal series distinctly reduced

(79) 0 , actinals uniform in outline and arrangement; 1 , actinals irregular in outline and/or arrangement, especially so away from the interbrachia

(80) 0 , actinals lacking pedicellarial alveolae; 1 , alveolae present

(81) 0, actinal accessories granulate; 1 , actinal accessories mostly or entirely spinelets; 2 , no accessories

(82) 0 , no unpaired first actinal; 1, an unpaired first actinal

Note: The first actinal is that adjacent to MAO, also morphologically differentiated in some taxa.

(83) 0 , enlarged actinal spines not developed; 1 , such spines developed

\section{Ambulacrals}

(84) 0, ambulacrals high, dorsal surface ridge-like; 1, ambulacrals low, dorsal surface rounded
(85) 0, ambulacral adradial longitudinal articular facet orientation distinctly overlapping; 1, facet orientation more or less upright, only weakly overlapping

(86) 0 , vertical outline of adradial body of ambulacral short and rectangular; 1, vertical outline elongate and triangular

(87) 0, abradial articular wings not subequal in vertical view; 1, wings subequal in vertical view

Adambulacrals

(88) 0, adambulacral distinctly wider than long; 1, approximately equidimensional; 2 , distinctly longer than wide

Note: Coding taken from proximal ossicles because adambulacral proportions can change along an arm, especially so in taxa with slender distal arms and enlarged disks.

(89) 0 , profile of furrow face of adambulacral flat; 1 , profile angled as to separate podia

(90) 0, furrow spines aligned in linear series; 1 , spines angled on each ossicle

(91) 0, furrow spines not clearly differentiated from lateral spine series; 1, furrow spines differentiated from lateral spine series

(92) 0, adambulacrals lack an enlarged subadambulacral spine; 1 , such a spine developed

\section{Appendix 2}

See Table 1 


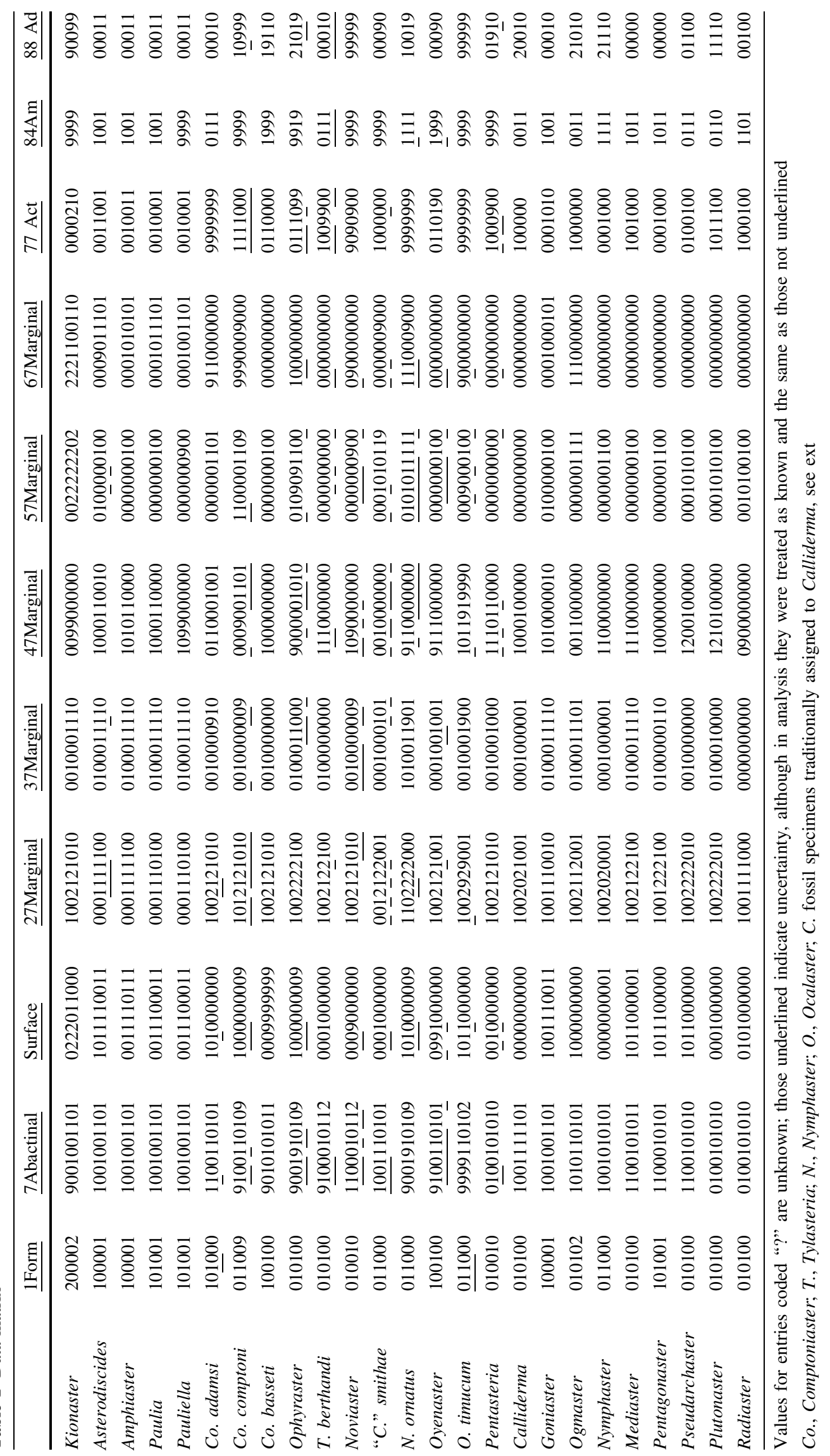




\section{References}

Akers, W. H. (1972). Planktonic foraminifera and biostratigraphy of some Neogene formations, northern Florida and Atlantic Coastal Plain. Tulane Studies in Geology and Paleontology, 9, 1-140.

Banks, J. E., \& Hunter, M. E. (1973). Post-Tampa, pre-Chipola sediments exposed in Liberty, Gadsden, Leon, and Wakulla counties, Florida. Gulf Coast Association of Geological Societies Transactions, 23, 355-363.

Bender, M. L. (1973). Helium-uranium dating of corals. Geochimica et Cosmochimica Acta, 37, 1229-1247.

Blake, D. B. (1978). The taxonomic position of the modern sea star Cistina Gray, 1840. Proceedings of the Biological Society of Washington, 91, 234-241.

Blake, D. B. (1983). Some biological controls on the distribution of shallow-water sea-stars. Bulletin of Marine Science, 33, 703-712.

Blake, D. B. (1990). Adaptive Zones of the Class Asteroidea (Echinodermata). Bulletin of Marine Science, 46, 701-718.

Blake, D. B. (2010). Comptoniaster adamsi nov. sp. (Echinodermata, Asteroidea) from the middle Cretaceous of Texas and its phylogenetic position. Geobios, 43, 179-190.

Blake, D. B., \& Elliott, D. R. (2003). Ossicular homologies, systematics, and phylogenetic implications of certain North American Carboniferous asteroids. Journal of Paleontology, 77, 476-489.

Blake, D. B., \& Hagdorn, H. (2003). The Asteroidea (Echinodermata) of the Muschelkalk (Middle Triassic of Germany). Paleontologische Zeitschrift, 77, 23-58.

Blake, D. B., \& Portell, R. W. (2009). Implications for the study of fossil Asteroidea (Echinodermata) of new genera and species from the Eocene of Florida. Journal of Paleontology, 83, $562-574$

Blow, W. H. (1969). Late middle Eocene to recent planktonic foraminiferal biostratigraphy. In: Bronnimann, P., Renz, H. H., \& Brill E. J. (Eds.), Proceedings of the First International Conference on Planktonic Microfossils (Geneva, 1967) (1, pp. 199-421). The Netherlands.

Bryant, J. D., Macfadden, B. J., \& Mueller, P. A. (1992). Improved chronologic resolution of the Hawthorn and the Alum Bluff Groups in northern Florida: implications for Miocene chronostratigraphy. Geological Society of America Bulletin, 104, 208-218.

Clark, A. M. (1993). An index of names of recent Asteroidea-Part 2. Valvatida. In: Jangoux, M., Lawrence, J. M., \& Balkema A. A. (Eds.), Echinoderm studies (pp. 187-366). Rotterdam.

Fisher, W. K. (1906). The starfishes of the Hawaiian Islands. Bulletin of the United States Fish Commission, 23, 987-1130.

Huddlestun, P. F. (1984). The Neogene stratigraphy of the central Florida panhandle. Unpublished Ph. D. dissertation (p. 245), Florida State University, Tallahassee.

Jones, D. S. (1997). The marine invertebrate fossil record of Florida. In: Randazzo, A. F., \& Jones, D. S. (Eds.), The geology of Florida (pp. 89-117). University Press of Florida.

Lane, D. J. W., \& Rowe, F. W. E. (2009). A new species of Asterodiscides (Echinodermata, Asteroidea, Asterodiscididae) from the tropical southwest Pacific, and the biogeography of the genus revisited. Zoosystema, 31, 419-429.

Liao, Y., \& Clark, A. M. C. (Eds.) (1995). The echinoderms of Southern China (p. 614). Beijing: Science Press.

Lourens, L., Hilgen, F., Shackleton, N. J., Laskar, J., \& Wilson, D. (2004). The Neogene Period. In: Gradstein, F. M., Ogg, J. G., \& Smith, A. G. (Eds.), A Geologic Time Scale 2004 (pp. 409-440). Cambridge University Press.

Ludwig, H. (1905). Asteroidea. Memoirs of the Museum of Comparative Zoology (32, p. 292).
Mah, C. L. (2005a). Cladistic analysis of the Goniasteridae (Asteroidea: Valvatoidea): phylogeny, evolution, and biodiversity. Unpublished Ph. D. dissertation (p. 308), Champaign: University of Illinois.

Mah, C. L. (2005b). A phylogeny of Iconaster and Glyphodiscus (Echinodermata, Asteroidea, Valvatida, Goniasteridae) with descriptions of four new species. Zoosystema, 27, 137-161.

Mah, C. L. (2006). Phylogeny and biogeography of the deep-sea goniasterid Circeaster (Echinodermata, Asteroidea, Goniasteridae) including descriptions of six new species. Zoosystema, 28, 917-954.

Mah, C. L. (2007). Systematics, phylogeny, and historical biogeography of the Pentagonaster clade (Asteroidea, Valvatida, Goniasteridae). Invertebrate Systematics, 21, 311-339.

Malay, M. C. D., \& Paulay, G. (2010). Peripatric speciation drives diversification and distributional pattern of reef hermit crabs (Decapoda: Diogenidae: Calcinus). Evolution, 64, 634-662.

O'Neill, P. L. (1989). Structure and mechanics of starfish body wall. Journal of Experimental Biology, 147, 53-89.

Oguro, C. (1991). Asterodiscides japonicus n. sp. In: Imaoka, T., Irimura, S., Okutani, S., Oguro, C., Oji, T., \& Kanazawa, K. (Eds.), Echinoderms from Continental Shelf and Slope around Japan (pp. 75-86). Tokyo: Japan Fisheries Resource Conservation Association.

Rowe, F. W. E. (1977). A new family of Asteroidea (Echinodermata), with the description of five new species and one new subspecies of Asterodiscides. Records of the Australian Museum, 31, 187-233.

Rowe, F. W. E. (1985). Six new species of Asterodiscides A. M. Clark (Echinodermata, Asteroidea), with a discussion of the origin and distribution of the Asterodiscididae and other 'amphi-Pacific' echinoderms. Bulletin Muséum national d'Histoire naturelle, Paris, sec. A, ser. $4^{\mathrm{e}}$ (7, pp. 531-577).

Schuchert, C. (1915). Revision of Paleozoic Stelleroidea with special reference to North American Asteroidea. Bulletin of the US National Museum (88, p.311).

Scolaro, R. J. (1968). Paleoecologic interpretation of some Florida Miocene Bryozoa (Preliminary Report). Atti Della Società Italiana Di Scienze Naturali E Del Museo Civico Di Storia Naturale Di Milano, 108, 174-177.

Spencer, W. K. (1915). British Palaeozoic Asterozoa. Part 2. Palaeontographical Society of London Monograph (pp. 57-108).

Spencer, W. K. (1920). British Palaeozoic Asterozoa. Part 5. Palaeontographical Society of London Monograph (pp. 197-236).

Spencer, W. K., \& Wright, C. W. (1966). Asterozoans. In: Moore, R. C. (Ed.), Treatise on Invertebrate Paleontology, Part U, Echinodermata. Lawrence: The Geological Society of America and the University of Kansas. (2(1) pp. U4-U107).

Villier, L., Blake, D. B., Jagt, J. W. M., \& Kutscher, M. (2004a). A preliminary phylogeny of the Pterasteridae (Echinodermata, Asteroidea) and the first fossil record: Late Cretaceous of Germany and Belgium. Paläontologische Zeitschrift, 78, 281-299.

Villier, L., Kutscher, M., \& Mah, C. L. (2004b). Systematics and palaeoecology of middle Toarcian Asteroidea (Echinodermata) from the "Seuil du Poitou", Western France. Geobios, 37, $807-825$.

Vokes, E. H. (1989). An overview of the Chipola Formation, northwestern Florida. Tulane Studies in Geology and Paleontology, 22, 13-24.

Weisbord, N. E. (1971). Corals from the Chipola and Jackson Bluff Formations of Florida. Florida Geological Survey Bulletin (53, p. 105). 